\title{
Diabetes Mellitus and Impaired Glucose Tolerance in $\beta$-Thalassaemia Major Patients with Secondary Haemchromatosis: Frequency and their Associations from a Developing Country
}

\author{
Sana Khurram*, Saqib Ansari, Muhammad Nadeem, Nida Anwar, Sadia Parveen, Omair Adil, Tahir Shamsi \\ Department of Haematology, National Institute of Blood Disease and Bone Marrow Transplantation Karachi, Pakistan.
}

\begin{abstract}
Objective: Diabetes mellitus is well-known endocrine complication of beta thalassaemia major patients. This study aims to determine the frequency of diabetes mellitus in BTM patients and to examine its association with age, height, weight, number of transfusions, serum Ferritin and total duration of blood transfusion.
\end{abstract} Methods: Fasting blood samples of BTM patients were analyzed for plasma glucose level by glucose oxidase method. Plasma fasting glucose
level $\geq 126 \mathrm{mg} / \mathrm{dl}$ on two occasions was considered as diabetes mellitus. Patients with fasting plasma glucose levels ranged from 100 to
$125 \mathrm{mg} / \mathrm{dl}$ were assessed further by oral glucose tolerance test (OGTT).

Results: Of 188 patients, $151(80.3 \%)$ were non-diabetic patients; frequency of diabetes mellitus and impaired glucose tolerance (IGT) was found in $11(5.8 \%)$ and $26(13.8 \%)$ patients respectively. Higher age group (median age 12.5 years) (p-value $<0.001)$, frequency of transfusion ( $\mathrm{p}$-value $<0.001)$, total duration of blood transfusion ( $\mathrm{p}$-value 0.007$)$ were found important risk factors.

Conclusion: Our findings confirmed the importance of screening and monitoring of blood sugar levels in thalassaemic patients. However, it also provides an insight regarding its associations with higher age raised serum Ferritin and total duration of blood transfusions.

Keywords: Diabetes mellitus, $\beta$-thalassaemia major, Impaired glucose tolerance, Oral Glucose Tolerance Test (OGTT), Haemochromatosis.

\section{INTRODUCTION}

ß-thalassaemia represents a group of recessively inherited haemoglobin disorders. The homozygous state known as BTM, results in a severe haemolytic anaemia requiring regular blood transfusions. However, frequent blood transfusions have been associated with iron overload [1-3]. 3 thalassaemia is the most common single gene disorder in Pakistan with a gene frequency of $5-8 \%$ and about $8-10$ million carriers in the country [4] and it is present in all ethnic groups [5].

Frequent blood transfusions lead to deposition of iron in multiple organs especially liver, heart, endocrine glands, skin and musculoskeletal system. Most clinical manifestations of iron overload do not appear until the second decade of life in patients with inadequate iron chelation. Endocrine abnormalities are among the most common complications of thalassaemia major [6-8].

Among these endocrine abnormalities, impaired glucose tolerance and diabetes mellitus are the major endocrinopathy which occurs due to transfusion related haemosiderosis and is found in $9-15 \%$ of patients with beta-thalassaemia worldwide, accounting for significant morbidity [9-11]. DM in thalassaemia patients is a distinct form of DM. It is peculiar in many aspects including its pathophysiology as it occurs due to *Address correspondence to this author at the Department of Haematology, National Institute of Blood Disease and Bone Marrow Transplantation Karachi, Pakistan. E-mail: drsanakhokher@yahoo.com resistance of insulin at target receptors, as well as islet cell insufficiency which can even lead to absolute deficiency of insulin [12].

A study of 142 chronically transfused patients with beta thalassaemia major noted diabetes mellitus in $14.6 \%$ cases with mean 12 years of transfusion and an average serum ferritin of $2000 \mu \mathrm{g} / \mathrm{l}$ [13].

Main risk factors associated with DM are poor compliance with iron chelation leading to secondary iron overload in pancreas resulting destruction of pancreatic $\beta$ cell, advanced age at the start of intensive chelation therapy, liver cirrhosis or severe fibrosis, viral infection and/or genetic factors $[14,15]$.

The strongest predictor for the development of diabetes in some studies was the amount and duration of transfusion therapy [16], with every decade of transfusion exposure increasing the odds of developing diabetes by a further 2.5 times [8].

There appears to be a reduction in the frequency of diabetes in patients who have been more adequately chelated [13]. A study reported overall diabetes rate of $10 \%$ [17] is less than the $20 \%$ reported in Brittenham and coworkers' cohort of 59 patients, aged 7 to 31 Years [18]. Diabetes mellitus increases the risk for cardiac complications; heart failure, hyperkinetic arrhythmias and myocardial fibrosis irrespective of myocardial iron overload [19, 20].

www.njhsciences.com 
Knowing the fact that DM is one of the well-known endocrine complications of $\beta$-thalassaemia major patients on transfusion therapy, this study had been designed to see the frequency of DM in BTM patients of Pakistan and its association with age, height, weight, number of transfusions, total duration of blood transfusion and serum ferritin. This will help us in planning an optimum transfusion therapy, proper and early iron chelation, prevention, monitoring and diagnosis of DM at an early stage and last but not the least prompt management of DM in this group of patients of developing country.

\section{PATIENTS AND METHODS}

The study was conducted at National Institute of Blood Disease \& Bone Marrow Transplantation Karachi. Sample size was calculated based on previously reported frequency of diabetes mellitus to be $14.6 \%$ [13]. Study design was descriptive cross sectional study and sample technique was non-probability purposive. Inclusion criteria were BTM patients confirmed on the basis of DNA analysis for thalassaemia mutations, Age 5 years and above and either gender. Exclusion criteria were $\beta$-thalassaemia trait and B-thalassaemia intermedia, Compound heterozygote cases of $\mathrm{HbD}, \mathrm{HbE}, \mathrm{HbS}$ or $\mathrm{HbC}$ trait either diagnosed on haemoglobin electrophoresis or thalassaemia gene mutation analysis, on medication known to cause glucose intolerance (e.g. corticosteroids), those diagnosed as cases of secondary diabetes mellitus (e.g. Cushing syndrome).

Patients with BTM meeting the inclusion criteria were enrolled in the study from haematology clinics. The study was approved from the institutional board/ethics committee. The purpose and procedure of the study was explained to the parents /patients. An informed consent was taken from each patient or their parents (in the case of minor). Patients were asked to visit with overnight fasting.

Blood samples were collected in the morning as a basal sample for estimation of plasma glucose in sodium fluoride tube, a glycolysis inhibitor containing potassium oxalate as an anticoagulant. $3 \mathrm{ml}$ of whole blood was taken from each patient. Samples were centrifuged at 6000rpm for 10 minutes in order to obtain plasma. One $\mathrm{ml}$ of glucose reagent was added in $10 \mathrm{ul}$ of plasma and incubated for $10 \mathrm{~min}$ at $370 \mathrm{C}$. Plasma samples were analyzed for glucose on STAT FAX 3300 , a spectrophotometer by glucose oxidase method.

Either fasting plasma glucose of $\geq 126 \mathrm{mg} / \mathrm{dl}$ on two occasions or venous plasma glucose of $\geq 200 \mathrm{mg} / \mathrm{dl}$, $2 \mathrm{~h}$ after ingestion of $75 \mathrm{~g}$ oral glucose load was considered diagnostic for diabetes mellitus [21]. For children, a dose of $1.75 \mathrm{~g} / \mathrm{kg}$ (to a maximum of $75 \mathrm{~g}$ ) was used for OGTT [22].

\section{STATISTICAL METHOD}

Data was analyzed on statistical software SPSS version 17. Frequency and percentage were computed for categorical data like gender and diabetes mellitus in thalassaemia major. Mean and SD were computed for numerical data like age, weight, height and duration of transfusion. Stratification was done with regard to age, gender, weight, number of transfusions and serum ferritin to observe the effect on the outcome variables through chi-square test. $P$ value $\leq 0.05$ was taken as significant.

\section{RESULTS}

\section{General Characteristics}

Out of total 188 studied patients, there were 83 (44.1\%) male. Median age was 12.5 (10-17) years. Median height and weight of the patients were $130(120-146) \mathrm{cm}$ and 26 (21-35) $\mathrm{kg}$ respectively. Median age at first transfusion was 7 (6-7) months. Based on plasma glucose levels, $11(5.8 \%)$ and 26 $(13.8 \%)$ patients had diabetes mellitus and impaired glucose tolerance (IGT) respectively. Diabetes status of the patients and its association with age, height, weight, age, age at first transfusion are discussed in detail in Table $\mathbf{1}$.

Table 1. Comparison of Diabetes Status with General Characteristics of the Patients.

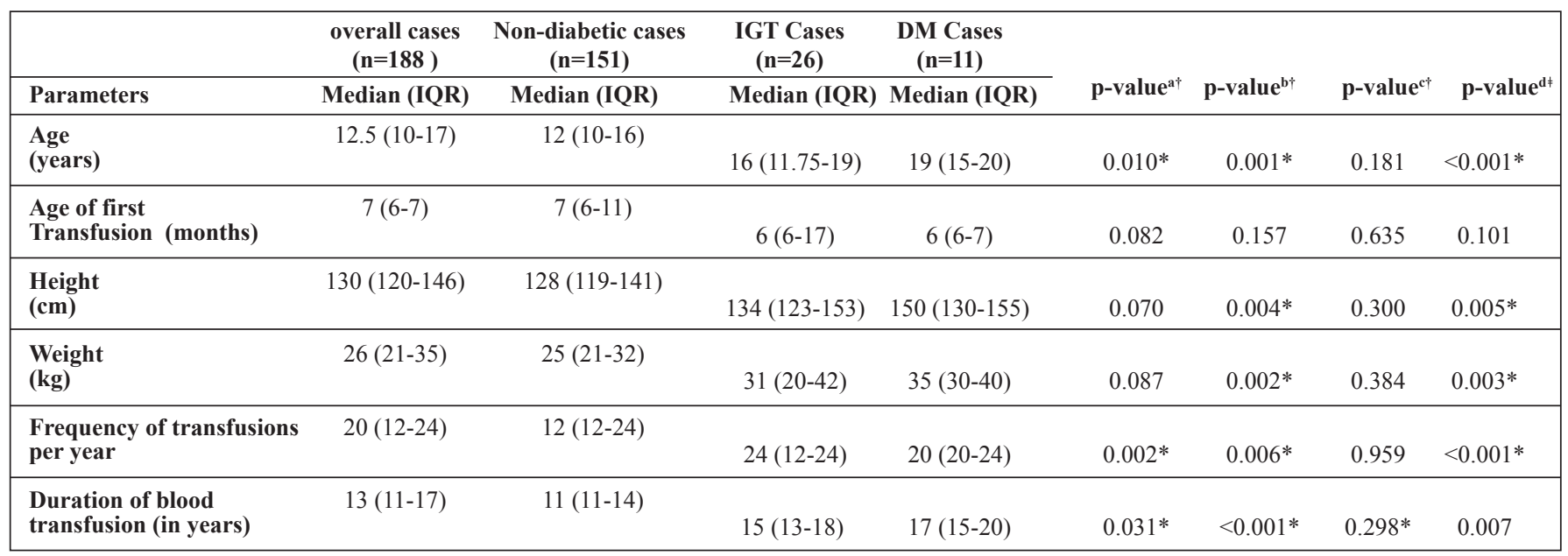

IGT: Impaired glucose tolerance test, DM: Diabetes Mellitus, SD: Standard Deviation

a: normal vs IGT cases, b: normal vs DM cases, c: IGT vs DM cases, d: normal vs IGT vs DM cases

$\dagger$ Mann-whitney U test applied, $¥$ Kruskal-Wallis test applied

$*$ p-value $<0.05$ 
$71(37.7 \%)$ patients, were taking tablet deferasirox, 68 (36.1\%) were on deferiprone, while 38 (20.2\%) patients were on desferrioxamina + deferiprone combination. No iron chelation therapy was received by 11 (5.9\%) patients (Fig. 1).

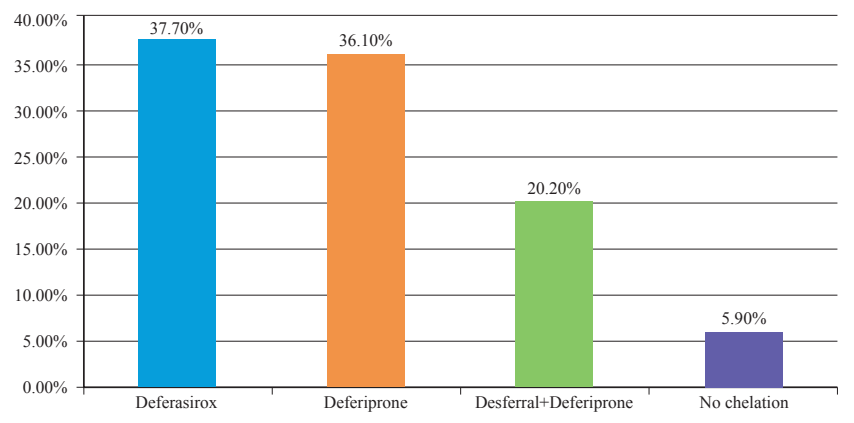

Fig. (1). Iron Chelation Therapy ( $\mathrm{n}=188)$.

Significant difference of serum ferritin level was observed in between non-diabetic vs. DM patients (p-value 0.043) and IGT vs. DM patients (p-value 0.023). However, insignificant difference was observed among non-diabetic vs. IGT (p-value 0.501 ) and normal vs. IGT vs. DM (p-value 0.083) (Fig. 2). Significant relationship was observed between serum ferritin and diabetic status (p-value 0.013) (Fig. 2).

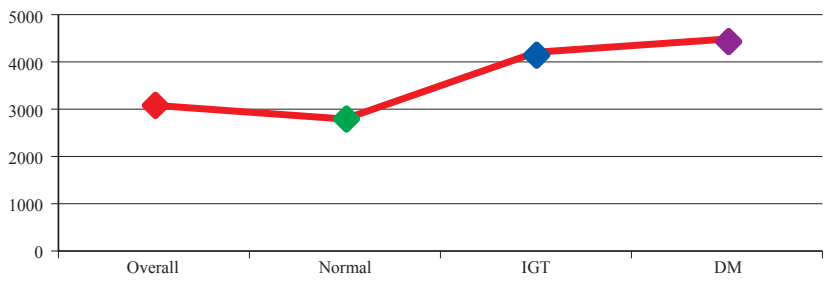

Fig. (2). Serum Ferritin level (in $\mathrm{ng} / \mathrm{ml}$ ) with Respect to Diabetic Status.

\section{DISCUSSION}

IThe frequency of DM in our study was low in contrast to the local study in which they retrospectively analyzed BTM patients for endocrinopathy [16]. Lower frequencies have also been demonstrated in our population [23, 24]. This is probably due to the fact that higher percentages of patients were on iron chelation. Our findings are comparable to those explained [25] in Iran. However, higher frequencies were reported in India [26], in Egypt [27], in Cyprus [28], in Oman [29] and in Tehran [30]. Poor iron chelation could be the most likely cause.

Of our total 188 patients, 105 were female demonstrating a female preponderance. This is in contrast to the results of some studies [31-33] reporting an opposite gender distribution.

In our study the median age at first blood transfusion in DM group was 6 years and is lower than reported by a multicenter study in Tehran, pointing towards the earlier transfusion need in our patient population [30]. Similar findings were observed in another study [34]. Higher age was reported in few studies [25-29]. The probable reasons of patients presented at higher age in these studies were that they enrolled the patients with advance age or their patients have received fewer blood transfusions as compare to our study so as the complications of iron overload may have manifested in advance age group.

In our study the median age of first blood transfusions for DM is lower than other study [30]. Lower median age at first transfusion for DM in our study explains that they have exposed to blood transfusion at an earlier age than those with non-diabetics. In our study the median duration of blood transfusions is almost similar to reported by a study [32].

In our study the median serum ferritin is significantly high in both the groups. Similarly higher serum ferritin was reported in other studies. [25, 32, 35].

A cross-sectional study of 382 BTM patients treated with regular transfusions and desferrioxamine, demonstrated that patients with serum ferritin level $>2,500 \mathrm{ng} / \mathrm{ml}$ were 3.53 times $(95 \%$ CI 1.0911 .40$)$ more likely to have DM [36]. Some studies have also reported that ferritin levels of patients with DM were not significantly different from those patients who had no DM $[30,34]$. This may be explained by pathophysiology other then pancreatic iron overload.

In our study the median frequency of blood transfusion per year is higher than the results obtained by a study [35]. Those who required frequent blood transfusions were more prone for diabetes and impaired glucose tolerance as compare to those who required less frequent blood transfusions.

\section{CONCLUSION}

Frequency of diabetes mellitus and impaired glucose tolerance (IGT) was found in $11(5.8 \%)$ and $26(13.8 \%)$ patients respectively out of 188 patients. We found an association of DM with higher ages, raised serum ferritin, increase number of blood transfusion and total duration of blood transfusions. These findings are not novel, but provide insights into the complications of thalassaemia in a developing country. It also highlights the possible prevention of IGT/DM in thalassaemic patients. Patients with BTM need periodic evaluation for early recognition and prevention of this complication by early and regular chelation therapy for the improvement of the quality of life. As persistence of high blood sugar levels in DM lead to various complications involving central nervous system, heart, fatal electrolyte imbalance and death, so one should be cautious and vigilant to screen these patients in second decade of life regularly for the development of DM. However, as this was a cross sectional study, more cohort follow on studies is needed. 


\section{ABBREVIATIONS}

OGTT Oral Glucose Tolerance Test

BTM $\beta$-Thalassaemia Major

DM Diabetes Mellitus

IGT Impaired Glucose Tolerance

IFG Impaired Fasting Glucose

\section{CONFLICT OF INTEREST}

Declared None.

\section{ACKNOWLEDGEMENTS}

We are particularly grateful to all participants in the study for their dedication and contribution to the research.

\section{Funding}

A funding of NIBD \& BMT research department supported this study.

The authors declare that there is no conflict of interest associated with this study.

\section{Contribution Statement}

Sana Khurram contributed to conception and design, acquisition, performed the statistical analyses and drafted the manuscript. Tahir Shamsi and Saqib Ansari contributed to conception, patient recruitment and manuscript revision. Muhammad Nadeem and Nida Anwar contributed to analysis and interpretation of data, and manuscript critical revision. Sadia Parveen and Omair adil contributed to patient's selection and data collection. All authors contributed to critical revisions and have read and approved the final manuscript.

\section{REFERENCES}

[1] Weatherall DJ. Haemoglobin and the inherited disorders of globin synthesis. In: Postgraduate Haematology. $5^{\text {th }}$ ed. Oxford: Blackwell Publishing Ltd. 2005; pp. 85-103.

DOI: $10.1002 / 9780470987056 . c h 6$

[2] Weatherall DJ. Disorders of Globin Synthesis: The Thalassaemias: Overview. In: Williams Hematology. $7^{\text {th }}$ ed. New York: McGraw-Hill Medical Publishing 2007; pp. 547-80.

[3] Olivieri NF, Weatherall DJ. Clinical aspects of $\beta$-thalassaemia and related disorders. In: Disorders of Haemoglobin Genetics, Pathophysiology and Clinical Management. $2^{\text {nd }}$ ed. UK: Cambridge University Press 2009; pp. 357-416.

DOI: $10.1017 / \mathrm{CBO} 9780511596582.024$

[4] Satwani H, Raza J, Alam M, Kidwai A. Endocrinal complications in thalassaemias: Frequency and association with ferritin levels. Pak Ped J 2005; 29(3): 113-9.
[5] Farzana T, Shamshi TS, Irfan M, Ansari SH, Baig MJ, Shakoor N. Peripheral blood stem cell transplantation in children with beta-thalassaemia major. J Coll Physicians Surg Pak 2003; 13: 204-6.

[6] Malik S, Syed S, Ahmed N. Complication in transfusion dependent patients of $\beta$-thalassaemia major. A Review. Pak J Med Sci 2009; 25(4):678-82.

[7] Farzad N, Akbar A, Naser A et al. A cross sectional study of metabolic and endocrine complications in B-thalassaemia major. Ann Saudi Med 2008; 28(5): 361-6.

DOI: $10.5144 / 0256-4947.2008 .361$

[8] Perera NJ, Lau NS, Mathews S, Waite C, Ho PJ, Caterson ID. Overview of endocrinopathies associated with $\beta$-thalassaemia major. Inter Med J 2010 40: 689-96.

DOI: $10.1111 /$ j.1445-5994.2010;02254.X

[9] Randa MM, Khalid EA, Amany MS. Gradient-echo magnetic resonance imaging study of pancreatic iron overload in young Egyptian $\beta$-thalassaemia major patients and effect of splenectomy. Diabetol Metabol Syndrome 2010; 2: 23.

DOI: $10.1186 / 1758-5996-2-23$

[10] Au WY, Lam WW, Chu W, et al. A T2* magnetic resonance imaging study of pancreatic iron overload in thalassaemia major. Haematologica 2008; 93: 116-9.

DOI: 10.3324/haematol.11768

[11] Forget BG. Thalassaemia syndromes. In: Hematology: Basic Principles and Practice. 3rd ed. New York: Churchill Livingstone 2000 ; p. 485

[12] Chatterjee R, Bajoria R. New concept in natural history and management of diabetes mellitus in thalassaemia major. Haemoglobin 2009; 33(Suppl 1): 127-30. DOI: $10.3109 / 09553000903347880$

[13] Farmaki K, Angelopoulos N, Anagnostopoulos G, Gotsis E, Rombopoules G, Tolis G. Effect of enhanced iron chelation therapy on glucose metabolism in patients with $\beta$-thalassaemia major. Br J Haematol 2006; 134(4): 438-44. DOI: $10.1111 /$ j.1365-2141.2006.06203.x

[14] Sanctis VD, Zurlo MG, Senesi TE. Insulin dependent diabetes in thalassaemias. Arch Dis Child 1988; 63: 58-62. DOI: 10.1136/adc.63.1.58

[15] Gamberini MR, Fortini M, Sanctis VD, Gilli G, Testa MR. Diabetes mellitus and impaired glucose tolerance in thalassaemia major: Incidence, prevalence, risk factors and survival in patients followed in the Ferrara Center. Pediatr Endocrinol Rev 2004; 2: 285-91. 
[16] Adil A, Sobani ZA, Jabbar A, Adil S, Awan S. Endocrine complications in patients of $\beta$-thalassaemia major in a tertiary care hospital in Pakistan. J Pak Med Assoc 2012; 62: 307-10.

[17] Cunningham MJ, Macklin EA, Neufeld EJ, Cohen AR. Complications of $\beta$-thalassaemia major in North America. Blood 2004; 104: 34-9. DOI: 10.1182/blood-2003-09-3167

[18] Brittenham GM, Griffith PM, Nienhuis AW. Efficacy of deferoxamine in preventing complications of iron overload in patients with thalassaemia major. N Engl J Med 1994; 331: 567-73. DOI: 10.1056/NEJM199409013310902

[19] Pepe A, Meloni A, Caruso V. Diabetes mellitus and cardiac complications in thalassaemia major patients. J Cardiovasc Magn Reson 2012; 14 (Suppl 1): 189.

DOI: 10.1186/1532-429X-14-S1-P195

[20] Theochari M, Ioannidou D, Nounopoulos H, et al. Ultrasonography as a function index, in children with $\beta$-thalassaemia. J Pediatr Endocrinol Metab 2000; 13(3): 303-06.

DOI: 10.1515/JPEM.2000.13.3.303

[21] Inzucchi SE. Diagnosis of diabetes. N Engl J Med 2012; 367: 542-50. DOI: 10.1056/NEJMcp1103643

[22] Cappellini M-D, Cohen A, Eleftheriou A, et al. Guidelines for the Clinical Management of Thalassaemia. Nicosia (CY): Thalassaemia International Federation 2008.

[23] Rahman M, Lodhi Y. Prospects and future of conservative management of beta thalassaemia major in a developing country. Pak J Med Sci 2004; 20: 105-12.

[24] Khan FR, Khan MH, Ayub T, Shah SH. Frequency of complications in beta thalassaemia major in D. I. Khan. Biomedica 2007; 23: 31-3.

[25] Mehrvar A, Azarkeivan A, Saberi NJ, Faranoush M, Mehrvar N, Vossough P. Prevalence of diabetes mellitus in patients with transfusion dependent $ß$-thalassaemia. IJBC 2008; 1: 23-7.

[26] Ramachandran A, Snehalatha C, Kapur A, et al. High prevalence of diabetes and impaired glucose tolerance in India: National urban diabetes survey. Diabetologia 2001; 44: 1094-101. DOI: $10.1007 / \mathrm{s} 001250100627$
[27] Khalifa AS, Salem M, Mounir E, El-Tawil MM, El-Sawy M, Abd Al-Aziz MM. Abnormal glucose tolerance in Egyptian beta thalassemic patients: Possible association with genotyping. Pediatr Diabetes 2004; 5: 126-32.

DOI: $10.1111 /$ j.1399-543X.2004.00051.x

[28] Toumba M, Sergis A, Kanaris C, Skordis N. Endocrine complications in patients with thalassaemia major. Pediatr Endocrinol Rev 2007; 5(2): 642-8.

[29] Mula-Abed W, Hashmi HA, Muslahi MA, Muslahi HA, Lamki MA. Prevalence of endocrinopathies in patients with Beta-thalassaemia major -a cross-sectional study in Oman. Oman Med J 2008; 23: 257-62.

[30] Shamshirsaz AA, Bekheirnia MR, Kamgar M, Pourzahedgilani N, Bouzari N, Habibzadeh M. Metabolic and endocrinologic complications in $\beta$-thalassaemia major: A multicenter study in Tehran. BMC Endocr Disord 2003; 3: 4.

DOI: 10.1186/1472-6823-3-4

[31] Torres FA, Bonduel M, Sciuccati G, et al. B-thalassaemia major in Argentina. Medicina 2002; 62(2): 124-34.

[32] Najafipour F. Evaluation of endocrine disorders in patients with thalassaemia major. Int J Endocrinol Metab 2008; 2: 104-13.

[33] Suvarna J, Ingle H, Deshmukh CT. Insulin resistance and beta cell function in chronically transfused patients of thalassaemia major. Ind Pediatr 2006; 43(5): 393-400.

[34] Kurtoglu AU, Kurtoglu E, Temizkan AK. Effect of iron overload on endocrinopathies in patients with ß-thalassaemia major and intermedia. Polish J Endocrinol 2012; 63: 260-63.

[35] Lana S, AL Ani MH. Impaired glucose tolerance test among ß-thalassaemia patients in Hawler Province, Iraq. Middle East J Fam Med 2012; 3: 18-25.

[36] Belhoul KM, Bakir ML, Saned MS, Kadhim AMA, Musallam KM, Taher AT. Serum ferritin levels and endocrinopathy in medically treated patients with $\beta$ thalassaemia major. Ann Hematol 2012; 91: 1107-14.

DOI: $10.1007 / \mathrm{s} 00277-012-1412-7$ 